\title{
From Shakespeare to Defoe: Malaria in England in the Little Ice Age
}

\author{
Paul Reiter \\ Centers for Disease Control and Prevention, \\ San Juan, Puerto Rico
}

\begin{abstract}
Present global temperatures are in a warming phase that began 200 to 300 years ago. Some climate models suggest that human activities may have exacerbated this phase by raising the atmospheric concentration of carbon dioxide and other greenhouse gases. Discussions of the potential effects of the weather include predictions that malaria will emerge from the tropics and become established in Europe and North America. The complex ecology and transmission dynamics of the disease, as well as accounts of its early history, refute such predictions. Until the second half of the 20th century, malaria was endemic and widespread in many temperate regions, with major epidemics as far north as the Arctic Circle. From 1564 to the 1730s-the coldest period of the Little Ice Age-malaria was an important cause of illness and death in several parts of England. Transmission began to decline only in the 19th century, when the present warming trend was well under way. The history of the disease in England underscores the role of factors other than temperature in malaria transmission.
\end{abstract}

The earth's climate has always been in a state of change. The past 250 to 300 years have seen a fairly steady warming trend. Average temperatures are now approaching those at the height of the Medieval Warm Period, near the end of the 12th century. The intervening centuries included a much colder period, the Little Ice Age, by far the most important climatic fluctuation in recent history (1). Such fluctuations, spanning several generations, are natural phenomena that have recurred several times in the past 10,000 years. They take place against a backdrop of episodes of longer duration and greater impact, such as the last Ice Age $(1,600,000$ to 10,000 years ago). In recent years, there has been growing concern that human activities may be modifying the natural climate. A decline in temperatures from the 1940s to the late 1970s gave rise to warnings that industrial pollutants were causing global cooling $(2,3)$. Subsequent warming has been attributed to increased concentrations of atmospheric carbon dioxide produced by burning fossil fuels, and other greenhouse gases (4). Climate models suggest that this trend could accelerate in the

Address for correspondence: Paul Reiter, Dengue Branch, Centers for Disease Control and Prevention, 2 Calle Casia, San Juan, Puerto Rico 00921-3200, USA; fax: 787-766-6596; e-mail: ipr1@cdc.gov. coming century, although the contribution of human-induced greenhouse gases to global temperatures is far from clear (4-6).

Discussions of the potential impact of human-induced global warming frequently include malaria, a disease widely perceived as tropical. Articles in the popular and scientific press have predicted that warmer temperatures will result in malaria transmission in Europe and North America (7-12). Such predictions, often based on simple computer models, overlook malaria's history; until recently, malaria was endemic and common in many temperate regions, and major epidemics extended as far north as the Arctic Circle (13). Despite the disappearance of the disease from most of these regions, the indigenous mosquitoes that transmitted it were never eliminated and remain common in some areas. Thus, although temperature is important in the transmission dynamics of malaria, many other variables are of equal or greater importance. This article reviews the history of the disease in a nontropical country-England-during the coldest years of the Little Ice Age.

\section{The Little Ice Age}

The 16th century is the first period for which we have a reliable history of climate and 


\section{Perspectives}

weather. Private diaries, ships' logs, accounts of military campaigns, and similar sources give descriptions of wind direction, wind speed, cloud formations, and other weather indicators. Precisely dated annals, chronicles, audited accounts, agricultural records, tax ledgers, and other archival material provide indirect information, particularly on extreme weather events, such as droughts, floods, or unusual cold. Additional evidence is available from glacial moraines, lake and ocean sediments, pollen strata, deposits of insects, tree rings, coral structure, radiometric analysis of ice cores, archaeologic sites, and many other sources. All this information can be combined to reconstruct past climates (Figure 1).

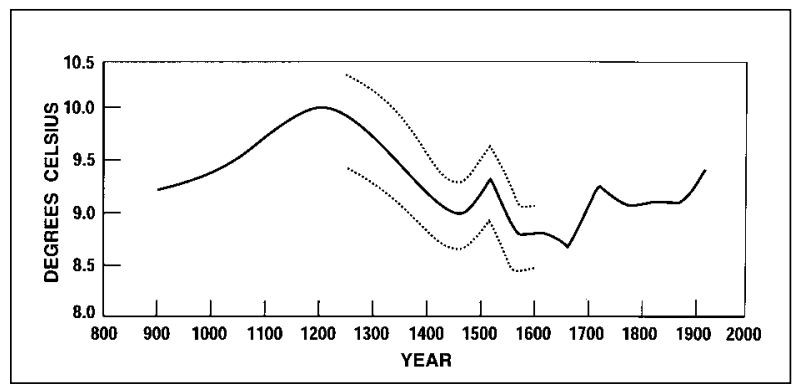

Figure 1. Estimated mean annual temperatures $\left({ }^{\circ} \mathrm{C}\right)$ prevailing in central England since A.D. 800. These are 50-year averages, based on a variety of proxy data (see text). Dotted lines indicate the range of apparent uncertainty of the derived values.

Redrawn from Lamb (1).

The first half of the 16th century appears to have been much warmer than the previous 150 years, which had seen a fairly steady decline in temperatures after the Medieval Warm Period. However, the new genial climate was not to last. In the middle of the century, after a decade or so of exceptionally warm years-warm enough for people to bathe in the Rhine in January-a drastically sharp change occurred. The winter 1564-65 was long and bitterly cold and was the first of many that brought great hardship and strife throughout Europe. Climatologists regard the next 150 to 200 years the climax of the Little Ice Age. On average, temperatures were probably lower than in any similar episode since the end of the last major Ice Age (14).

The impact of this sudden change of climate was dramatic and global (1). Glaciers advanced rapidly in Greenland, Iceland, Scandinavia, and the Alps. The Arctic pack ice extended so far south that there are six records of Eskimos landing their kayaks in Scotland. Large tracts of land, particularly at higher latitudes and altitudes, had to be abandoned. In many years, snowfall was much heavier than recorded before or since, and the snow lay on the ground for many months longer than it does today. Many springs and summers were outstandingly cold and wet, although there was great variability between years and groups of years. Crop practices throughout Europe had to be altered to adapt to the shortened, less reliable growing season, and there were many years of dearth and famine. Violent storms caused massive flooding and loss of life. Some of these resulted in permanent losses of large tracts of land from the Danish, German, and Dutch coasts. The dramatic cooling was captured in the paintings of the Flemish artist Pieter Bruegel (c. 1525-1569), who initiated a new genre by completing at least seven winter landscapes in 2 years (Figure 2).

Climate changes were equally striking in other parts of the world. In Ethiopia and Mauritania, permanent snow was reported on mountain peaks at levels where it does not occur today. Timbuktu, an important city on the transSaharan caravan route, was flooded at least 13

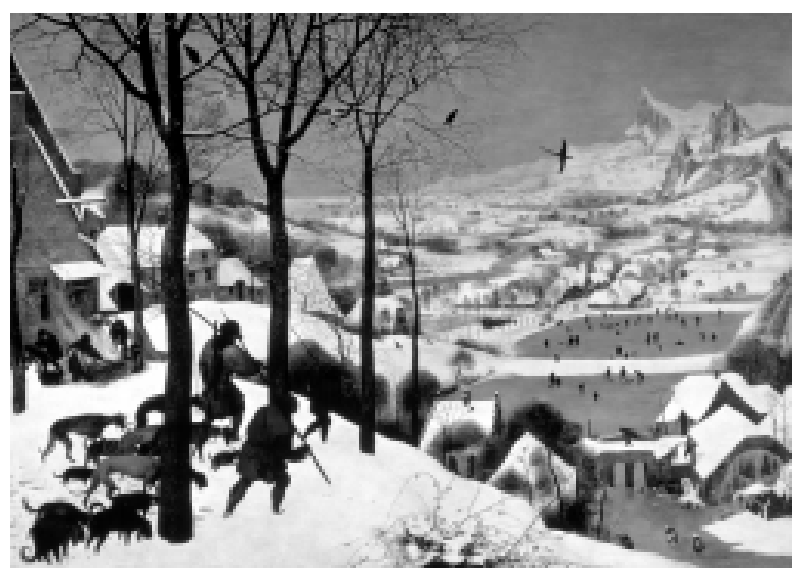

Figure 2. Hunters in the Snow by the Flemish painter Pieter Bruegel the Elder (1525-1569). Completed in February 1565, during the first of the many bitter winters of the Little Ice Age. Bruegel painted at least seven such snow scenes, including biblical themes such as Adoration of the Magi (in a snowstorm) and the Census at Bethlehem, and the genre was adopted by other painters of the period. Despite the cold, malaria persisted in northern Europe until the second half of the 20th century. The World Health Organization declared Holland free of the disease in 1970.

Reproduced courtesy of the Kunsthistorisches Museum, Vienna. 


\section{Perspectives}

times by the Niger River; there are no records of similar flooding before or since. In China, warm weather crops, such as oranges, were abandoned in Kiangsi Province, where they had been grown for centuries. In North America, the early European settlers also reported exceptionally severe winters. For example, in 1607 to 1608 ice persisted on Lake Superior until June (1).

\section{Ague}

The identity of diseases described in early literature is often uncertain, but fevers with a periodicity described as tertian or quartan are highly suggestive of malaria. Descriptors in the context of such accounts are often supportive. For example, in temperate regions, epidemic transmission of malaria tended to occur in late summer and autumn, giving rise to the common terms aestivo-autumnal or harvest fever for tertians and quartans.

During the Medieval Warm Period, mention of malarialike illness was common in the European literature from Christian Russia to caliphate Spain: "As one who has the shivering of the quartan so near,/ that he has his nails already pale/ and trembles all, still keeping the shade,/ such I became when those words were uttered." (The Inferno, Dante [1265-1321]).

The English word for malaria was ague, a term that remained in common usage until the 19th century. The Medieval Warm Period was already on the wane when Geoffrey Chaucer (1342-1400) wrote, in the Nun's Priest's Tale, "You are so very choleric of complexion./ Beware the mounting sun and all dejection,/ Nor get yourself with sudden humours hot;/ For if you do, I dare well lay a groat/ That you shall have the tertian fever's pain,/ Or some ague that may well be your bane."

Such mention of agues did not disappear when the coldest years of the Little Ice Age began. In 16th century England, many marshlands were notorious for their aguestricken populations and remained so well into the 19th century. William Shakespeare (15641616), who was born in the autumn of Bruegel's first fierce winter, mentioned ague in eight of his plays. For example, in The Tempest (Act II, Scene II), the slave Caliban curses Prosper, his master: "All the infections that the sun sucks up/ From bogs, fens, flats, on Prosper fall and make him / By inch-meal a disease!" Later, Caliban is terrified by the appearance of Stephano, who, mistaking his trembling and apparent delirium for an attack of malaria, tries to cure the symptoms with alcohol: “. . . (he) hath got, as I take it, an ague ... he's in his fit now and does not talk after the wisest. He shall taste of my bottle: if he have never drunk wine afore it will go near to remove his fit ... Open your mouth: this will shake your shaking ... if all the wine in my bottle will recover him, I will help his ague."

Alcohol and opium were commonly used to suppress the rigors of the first stage of the malarial paroxysm (15). We can assume that Shakespeare's audience was familiar with such details, although the play, one of his last, was probably not presented until 1611, long after the change to a colder climate.

\section{Geographic Distribution: the Marsh Parishes}

Five indigenous species of Anopheles mosquito are capable of transmitting malaria in England. The most competent, An. atroparvus, prefers to breed in brackish water along river estuaries. Contemporary accounts of the distribution of ague in 16th and 17th century England reflect the ecology and distribution of this species. For example, the anaerobic bacterial flora of saline mud produces a strong and distinctive sulfurous odor. This was widely perceived to be the actual cause of agues in salt marsh areas-Shakespeare's "unwholesome fens"- hence the Italian term mala aria (bad air).

The history of malaria in England and its demographic, epidemiologic, and social impact have been described in detail (16). Descriptions by 17 th century topographers of the airs and waters surrounding settlements along the River Medway (a tributary of the Thames estuary) alluded to this association (17). Thus, Upchurch, a town on the open estuary: "lies in a most unhealthy situation, close to the marshes ... the noxious vapours arising from which subject the inhabitants to continued intermittents." In nearby Iwade: " . . . in summer dry weather, the stench of the mud in the ponds and ditches. . . contribute so much to its unwholesomeness, that almost everyone is terrified to live in it ..." In Burnham, further upstream, the air was: "rather more healthy ... owing to the marshes being fewer and less offensive than those lower down the river. .." and finally, the freshwater reaches were "far more healthy . . . instead of the noisesome smells, arising from the salt marshes 


\section{Perspectives}

... the river here is encompassed with a range of pleasant fertile meadows, greatly conducive both to health and pride."

Even vicars of the Church were afraid of living in the estuarine areas. Dobson (15) reviewed several questionnaire surveys conducted by their bishops that asked "Do you reside personally upon your Cure, and in your Parsonage House? If not, where do you reside? What is the reason for your nonresidence?"

Nearly all the vicars of coastal "marsh parishes" answered no to the first question (Dobson lists 28 such parishes from the counties of Essex and Kent), and gave reasons such as "the place is so very Agueish," "frequently taken with agues and fevers," "the Thames having a very foul shore in this parish . . . attacked by so many repeated agues," "so violently afflicted with the worst of agues and languishing so long under it till our constitutions were almost broke," and "so unhealthy a situation as to be absolutely unfit for any curate."

Demographic data give striking justification for the vicars' fears (16) (Figures 3 and 4, Table). Descriptions of the marsh inhabitants resemble those of malaria-endemic area populations in the tropics today. Visitors commented on the swollen bellies of the children and their sallow, sickly faces, suggestive of anemia. An enlarged spleen was called ague cake. Nevertheless, despite the coldness of the climate, there is no indication that there was any major change in these death rates during the 17 th century.

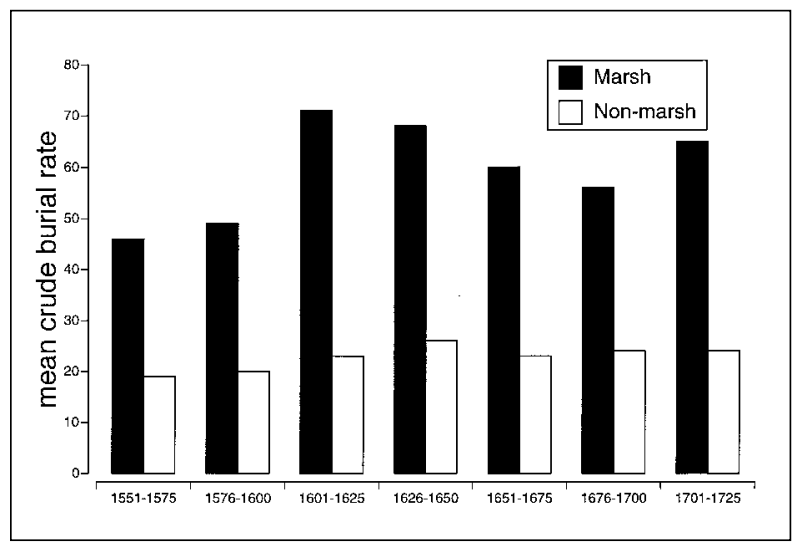

Figure 3. Average crude burial rates in Kent and Essex parishes, 1551-1750.

Drawn from Dobson (15).

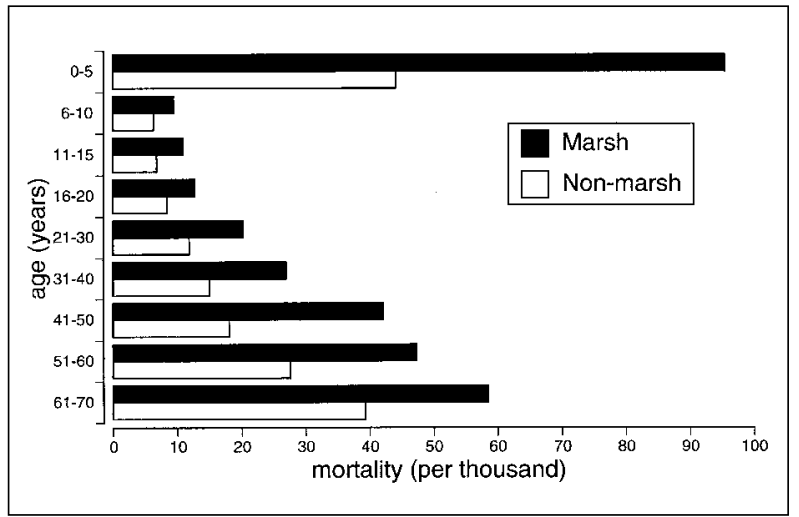

Figure 4. Age-specific death rates (per 1,000) in Essex parishes, c. 1800.

Drawn from Dobson (15).

Table. Deaths per 1,000 per year in late 18th century England (17) and 20th century Nigeria (39)

\begin{tabular}{lcccc}
\hline & \multicolumn{2}{c}{ Essex, England } & \multicolumn{2}{c}{ Garki, Nigeria } \\
Age & Nonmarsh & Marsh $^{\mathrm{a}}$ & Age & Savanna \\
\hline 5 & 44 & 95.3 & $1-4$ & 154 \\
$6-10$ & 6.3 & 9.4 & $5-8$ & 15 \\
$11-15$ & 6.8 & 10.8 & $9-18$ & 10 \\
$16-20$ & 8.4 & 12.7 & $19-28$ & 6 \\
\hline
\end{tabular}

aThe high death rates in the marsh parishes are attributable to malaria and were actually lower than in the previous century during the peak of the Little Ice Age. Moreover, the Essex data are skewed because many of the marsh communities included predominantly men. The rate was similar to that measured in the 1970s by the World Health Organization in a malaria-endemic area of sub-Saharan Africa.

Not all the summers of the 17th century were equally cool. The diarist Samuel Pepys (16331703), who himself had ague, wrote that the summers of 1661,1665 , and 1666 were dry and remarkably hot. This may well have enhanced transmission rates, for Thomas Sydenham described an epidemic of tertian and some quartan fevers in 1661, which "was doing frightful mischief" by August. Drought malaria, common in many parts of the world, arises when rivers and ponds are reduced to the smaller pools and puddles that anopheline mosquitoes prefer for breeding. Dobson (15) found a positive correlation between warm, dry summers in 1660 to 1810 and seasonal burial rates in Bradwelljuxta-Mare, a marsh parish in Essex. Macdonald (18) showed a strong relationship between high summer temperatures and cases of ague in Kent in the mid-19th century. High was defined as days when the temperature rose above $16^{\circ} \mathrm{C}$, as measured at the Royal Greenwich Observatory. 


\section{Perspectives}

Such hot weather, though clearly not tropical, could certainly have increased the probability of transmission by shortening the extrinsic incubation period (the time required for the mosquito to become infective after feeding on an infected person). Nevertheless, agues were not restricted to the warmer years.

\section{Clinical Descriptions}

Some accounts of intermittent fevers during the Little Ice Age were by physicians whose emphasis on precise methods, detailed observations, and accurate records leave us in no doubt that they were referring to malaria. William Harvey (1578-1657) made careful pre- and postmortem observations of cases of ague in London hospitals (St. Bartholomew's and St. Thomas'). ${ }^{1}$ His interest was probably sharpened because a persistent ague had caused him to miss much of his final year (1598-99) at the University of Cambridge. In his treatise on the circulation of the blood Exercitatio Anatomica de Motu Cordis et Sanguinis in Animalibus (1628), he gave a detailed description of the clinical pathologic features of the febrile episodes: "In tertian fever ... in the first instance ... the patient (is) shortwinded, disposed to sighing, and indisposed to exertion ... the blood (is) forced into the lungs and rendered thick. It does not pass through them (as I have myself seen in opening the bodies of those who had died in the beginning of the attack), when the pulse is always frequent, small, and occasionally irregular; but the heat increasing . . . and the transit made, the whole body begins to rise in temperature, and the pulse becomes fuller and stronger. The febrile paroxysm is fully formed ..."

Obstruction of circulation-commonly termed sludging-is mainly seen in Plasmodium falciparum infections. It results from complex changes in the consistency of the blood (19) and is manifest in many organs, although most often cited in the context of cerebral malaria. As Harvey noted, this dangerous condition often occurs suddenly, soon after the initial symptoms of a paroxysm.
Thomas Sydenham (1624-1689) is widely regarded as a founder of clinical medicine and epidemiology. His book on fevers (1666), which was later expanded into Observationes Medicae (1676), a standard text for 2 centuries, includes extensive details of agues, with descriptions of the course of paroxysms, the periodicity of tertians versus quartans, and the seasonality of the disease. As with Harvey, there can be no doubt that his descriptions refer to malaria; moreover, he states, "When insects do swarm extraordinarily and when . . . agues (especially quartans) appear early as about midsummer, then autumn proves very sickly." We cannot assume that insects referred to mosquitoes, but the statement that an early appearance of quartans was a premonition of a high incidence of illness (presumably agues?) has the distinct ring of modern epidemiology. Nevertheless, it is clear from these and other sources that the disease remained prevalent, even in the coldest years. For example, Harvey's ague began in the fall of 1597, yet the years 1594 to 1597 had been so cold and wet that wheat harvests were a disaster (1). Similarly, in 1657 to 1658 , snow lay on the ground for 102 days-indicating exceptionally cold weather even for the times. The summer crops were a disaster, yet Oliver Cromwell (1599-1658) died of a tertian ague in September 1658, just as another severe winter was setting in.

\section{Malaria Species}

$P$. vivax and $P$. falciparum both have a tertian periodicity, so it is unclear which species was responsible for tertiary ague in England. $P$. vivax can persist for many years as a dormant hypnozoite in the liver, giving rise to occasional clinical relapses (caused by production of the blood stages of the parasite), whereas there is no evidence of hypnozoites in $P$. falciparum. Twentieth-century studies in Russia and Holland showed that some strains of $P$. vivax from the northern hemisphere-given the subspecific name $P$. vivax hibernans-did not produce clinical symptoms until 8-9 months after the infective bite. Both features would clearly

${ }^{1}$ St. Thomas' Hospital (1213), in the Borough of Lambeth, was on the edge of the River Thames, surrounded by tidal marshes. Parliament met in two buildings at a similar site in the Borough of Westminster, directly across the river. Both areas were notoriously malarious. Centuries later, the American Founding Fathers followed British parliamentary procedure in choosing a site for their new nation's capital at the edge of a malarious swamp, later referred to as "A Mud-hole Equal to the Great Serbonian Bog." The Serbonian Bog probably refers to the vast flood plains of the Danube that border northern Serbia and Bulgaria. The Balkan region was the last major stronghold of malaria in Europe. Malaria was finally eliminated there in 1975. 


\section{Perspectives}

have survival value for $P$. vivax in a temperate climate, enabling it to cope with long winters and episodes of successive cold summers. On the other hand, $P$. vivax is generally a more benign pathogen than $P$. falciparum, but the death rate in the English marsh parishes suggests that infections were far from benign. This may indicate that $P$. falciparum was also present, and Harvey's observations on the consistency of blood in fatal cases support this possibility.

Laboratory studies have shown that tropical strains of $P$. falciparum do not multiply in European mosquitoes. However, European strains did cause major epidemics in Russia and Poland in the 1920s, with high death rates as far north as Archangel, Russia. In Holland, mosquitoes sheltering in the warmth of stables and human habitations continued to feed and transmit malaria throughout the winter and during colder summers. Thus, the dormancy and delayed onset of $P$. vivax were probably not essential for transmission, and it is conceivable that $P$. falciparum was endemic in England during the Little Ice Age. Alternatively, a more virulent strain of vivax may have been present. The question may never be resolved because the strains involved are now extinct.

\section{The Cure}

The strongest evidence that ague was indeed malaria is the identity of its cure. Until the mid20th century, the only effective remedy for malaria-at least in western medicine-was an extract of cinchona powder, obtained from the bark of several tree species native to the Andes, in South America. The principal active ingredient in this bark is quinine, a drug that has probably benefited more people than any other in the combat of infectious disease. Quinine is still used today, but few people know that its effective use for malaria therapy was first developed in tests with ague patients living in the salt marshes of Essex, less than $50 \mathrm{~km}$ from the center of London. What is more, the field experimentation that led to this English remedy was conducted during the coldest years of the Little Ice Age.

The first prescription of cinchona powder in England is attributed to Robert Brady in 1660. Thomas Sydenham advocated its use in his Methodus curandi febres in 1666. By that time, the "Jesuit's Powder" was already widely known in Europe, but in Protestant England many orthodox physicians were prejudiced against its use-partly because its export from Peru and Bolivia was in the hands of Catholics and its use had not been mentioned in the classical medical texts of Galen and partly because a reliable prescription had not been developed. In the end, popularization of the drug came in a highly unorthodox manner: a relatively untutored man, Robert Talbor, abandoned his apprenticeship to an apothecary to develop a safe dosage and an effective treatment regimen: "I planted myself in Essex near the sea side, in a place where agues are the epidemical diseases, where you will find but few persons but either are, or have been afflicted with a tedious quartan." After several years of study and testing, he developed what we would now call a patent medicine, a secret formulation that was essentially an infusion of cinchona powder in white wine.

In 1672, Talbor popularized his remedy by publishing Pyretologia: a Rational Account of the Cause and Cures of Agues. The success of his treatments became widely known and brought him rapid fame and fortune. Charles II appointed him Physician Royal in 1672 . He was knighted in 1678, after he cured the King of an ague (20). Sir Robert Talbor then traveled to France, where he cured the son of Louis XIV. With the additional title of Chevalier Talbot, he became famous throughout Europe, curing Louis XIV, Louisa Maria, Queen of Spain, and hundreds of other royal and aristocratic persons (Figure 5).

Talbor's rise to fame has been told in many publications $(21,22)$, yet none of these mention that the entire story took place in a period when temperatures were probably colder than in any other period in the past 10,000 years. Records for central England from 1670 to 1700 suggest that snow lay on the ground for an average of 20 to 30 days (in some years more than 100 days) as opposed to 2 to 10 days in the present century. In the winter 1683-84, the ground was frozen to more than $1 \mathrm{~m}$. Belts of sea ice $5 \mathrm{~km}$ wide were present along the coast in the English Channel and are believed to have been 30 to $40 \mathrm{~km}$ wide off the coast of the Netherlands. The average summer growing season was approximately 5 weeks shorter than in the 20th century, and in some years the difference may have been more than 2 months (1). Nevertheless, the fact that the European aristocracy was eager to pour money and honors on an untutored commoner suggests that malaria continued to be a serious problem. 


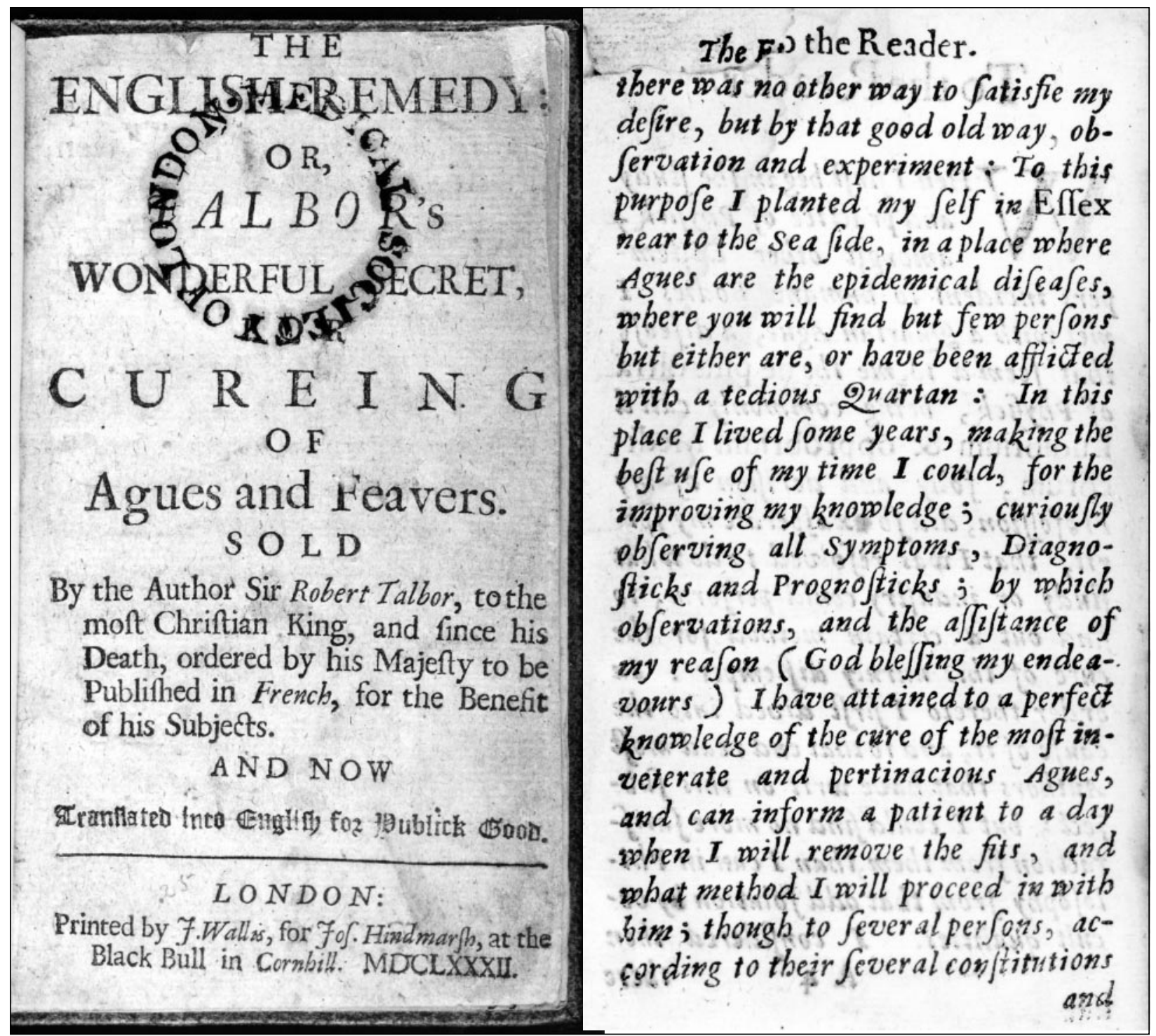

Figure 5. The English Remedy: Talbor's Wonderful Secret for Curing of Agues and Feavers (1682). Robert Talbor sold the secrets of his malaria treatment to King Louis XIV for 2,000 guineas, on condition that they would not be published until after his death. In 1682, Talbor's remedy was published in French; the English translation appeared in the same year. Front page of English translation and introductory page in which Talbor describes how he went to Essex, and used "that good old way, observation and experiment ... by which observations, and the assistance of my reason (God blessing my endeavours) I have attained a perfect knowledge of the cure of ... Agues."

Reproduced courtesy of Wellcome Institute for the History of Medicine, London.

\section{Defoe and Beyond}

Robinson Crusoe was shocked to discover that a footprint in the sand was not his own: "so that I shook with cold, like one in an ague." His creator, Daniel Defoe (1660-1731), had traveled extensively in southern England in 1685 to 1690. In A Tour through the Whole Island of Great
Britain (23), he described the depredations of ague in the Dengie marshes of Essex (Figure 6), an area $70 \mathrm{~km}$ east of London that remained notorious for the disease until the end of the 18th century (15): “... our London men of pleasure ... go from London on purpose for the pleasure of shooting [the abundant wildfowl] but those gentlemen who ... go 


\section{Perspectives}

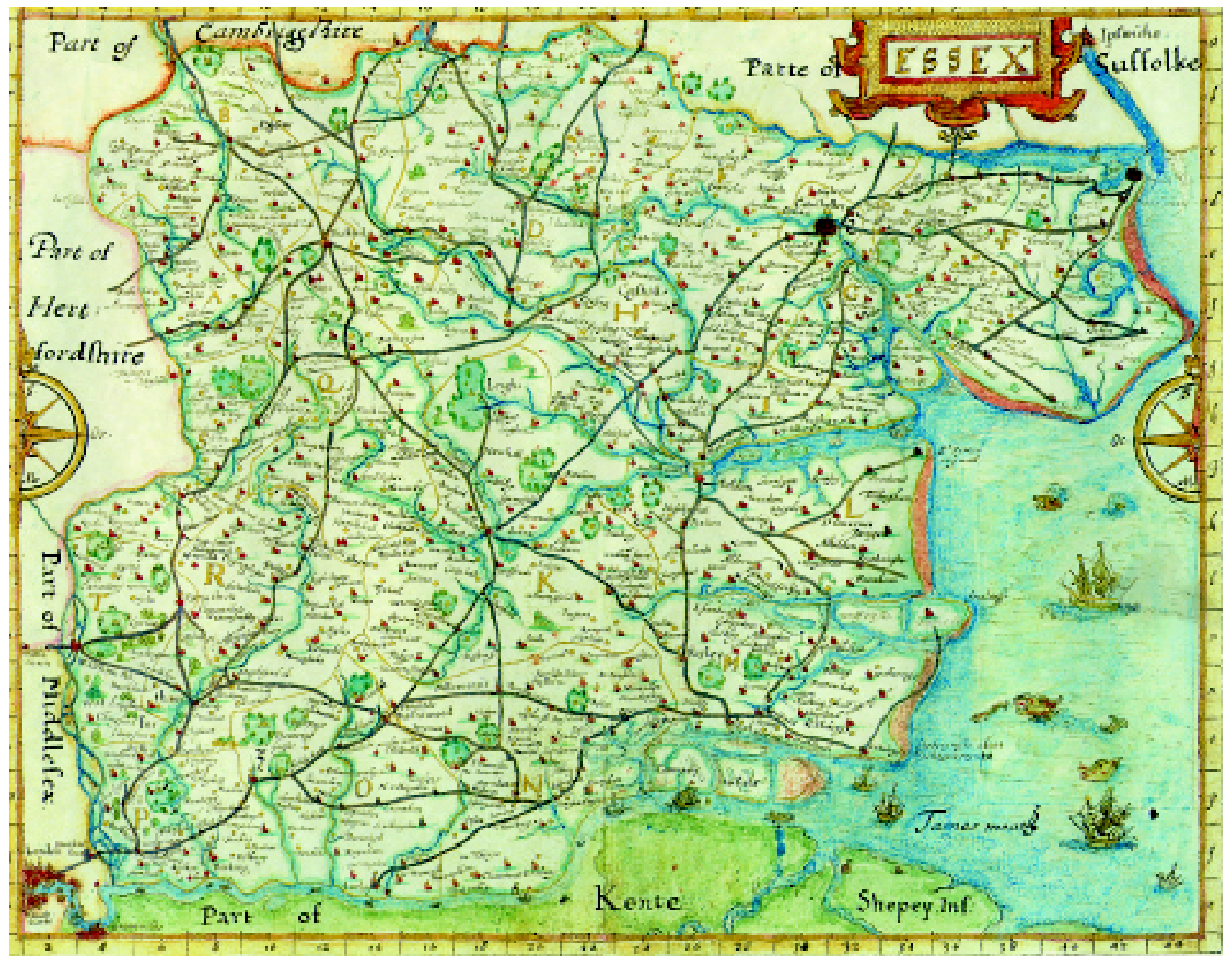

Figure 6. Map of the county of Essex in 1594. The extensive coastal salt marshes provided high-quality grazing for sheep and cattle but were also a favored habitat for An. atroparvus, a highly effective malaria vector. The disease was a major cause of illness and death in the area until the end of the 18th century.

Reproduced courtesy of Essex Record Office.

so far for it, often return with an Essex ague on their backs, which they find a heavier load than the fowls they have shot."

These sportsmen may have been wealthy enough to buy Talbor's remedy, but ordinary people suffered greatly in these unhealthy marshes. They risked living there because, as the land was excellent for rearing high-quality sheep and cattle, landlords were willing to pay high wages: “ . . f for it being a place where every body cannot live, those that venture it, will have encouragement, and indeed it is but reasonable they should."

However, as in the malarious tropics today, the nonimmune were in great danger. Thus Defoe observed: "a strange decay of the [female] sex here ... it was very frequent to meet with men that had had from five to six, to fourteen or fifteen wives ... the reason ... was this; that they [the men] being bred in the marshes themselves, and seasoned to the place, did pretty well with it; but that they always went into the hilly country ... for a wife: that when they took the young lasses out of the wholesome and fresh air, they were healthy, fresh and clear, and well; but when they came out of their native aire into the marshes . . . they presently changed their complexion, got an ague or two, and seldom held it above half a year, or a year at most; and then ... [the men] would go to the uplands again, and fetch another; so that marrying of wives was reckoned a kind of good farm to them." 


\section{Perspectives}

During the 18th century, temperatures began to return to pre-mid-16th century levels. However, the wide variability of the Little Ice Age continued for at least 150 years. In the 1770 s, much as today, alarm that the climate was becoming increasingly erratic prompted new emphasis on the recording of weather variables.

There are numerous accounts of malaria in all the northern European countries in the 18th and early 19th centuries. The wealth of records in this period confirms that the disease was common at many coastal sites in England and in some parts of Scotland, with occasional transmission as far north as Inverness $\left(57^{\circ} 20^{\prime}\right)$. The northern limit (24) was roughly along the $15^{\circ} \mathrm{C}$ July isotherm-not the $15^{\circ} \mathrm{C}$ winter isotherm, as stated by some authors $(8,10)$. Thus, there was endemic transmission in southern Sweden and Finland, with occasional devastating epidemics that extended to the northern end of the Gulf of Bothnia, close to the Arctic Circle $(25,26)$. In North America transmission occurred throughout most of the United States (27) and in some parts of Canada (28).

In 1827, John Macculloch (29) wrote "We may take the average of life among ourselves, in round numbers, at fifty with sufficient safety for this purpose. In Holland it is twenty-five; the half of human life is cut off at one blow, and the executioner is malaria, for there is no other cause for the superior mortality of that country."

The same was probably true of the coastal marshes of England, although the incidence appears to have decreased over the century. After the 1880s, transmission dropped precipitously, and the disease became relatively rare, except during a short period following World War I. This decline cannot be attributed to climate change, for it occurred during a warming phase, when temperatures were already much higher than in the Little Ice Age. Factors contributing to the decline include the following: Mosquito habitat was eliminated by improved drainage and extensive land reclamation. Root crops, such as turnips and mangel-wurzels, were introduced as winter fodder, enabling farmers to maintain much greater numbers of animals throughout the year; this diverted An. atroparvus, a zoophilic species, from feeding on humans. Rural populations declined as manual labor was replaced by machinery, further reducing the availability of humans as hosts for both mosquitoes and parasites. New building materi- als and improved methods of construction made houses more mosquito-proof, especially in winter, thus reducing the risk for contact with mosquitoes. Greater access to medical care and a rapid drop in the cost of quinine reduced the survival rate of the malaria parasite in its human host.

A similar decline occurred in the more prosperous countries of Europe-Norway, Sweden, Denmark, Germany, Holland, Belgium, France, and northern Italy. However, malaria maintained a much firmer grip on Eastern Europe-Finland, Poland and Russia, and the countries bordering the Black Sea and the eastern Mediterranean. It was not until the advent of DDT, after World War II, that a concerted attempt could be made to eradicate the disease from the entire continent (30). At the same time, the Communicable Disease Center (forerunner of the Centers for Disease Control and Prevention) was set up in Atlanta to eliminate malaria from the United States, where it was still endemic in 36 states (27), including Washington, Oregon, Idaho, Montana, North Dakota, Minnesota, Wisconsin, Iowa, Illinois, Michigan, Indiana, Ohio, New York, Pennsylvania, and New Jersey.

\section{Conclusion}

In 1975, the World Health Organization declared that Europe was free of malaria. The last indigenous case in England had been in the 1950s and in Bruegel's Holland in 1961. Results were equally spectacular on other continents. By $1977,83 \%$ of the world's population was living in regions from which malaria had been eradicated or control activities were in progress. The only areas in which the control effort was limited were those of high endemic stability, particularly sub-Saharan Africa.

However, this momentum could not be sustained, and the goal of worldwide eradication was abandoned. Today, the disease is again common in many parts of Central America, the northern half of South America, much of tropical and subtropical Asia, some Mediterranean countries and many of the republics once part of the Union of Soviet Socialist Republics. This rapid recrudescence has been attributed to population increase, forest clearance, irrigation and other agricultural activities, ecologic change, movement of people, urbanization, deterioration of public health services, resistance to insecticides 


\section{Perspectives}

and antimalarial drugs, deterioration of vector control operations, and disruptions from war, civil strife, and natural disasters. Claims that malaria resurgence is due to climate change ignore these realities and disregard history. For example, the many statements that recent climate change has caused malaria to ascend to new altitudes $(10,31,32)$ are contradicted by records of its distribution in 1880 to 1945 (33-35).

With the return of malaria, there has been an exponential rise in international travel. Tens of thousands of cases are imported into Europe and North America each year. As was anticipated 30 years ago (36), a few of these cases give rise to autochthonous transmission by indigenous mosquitoes.

In much of Western Europe, the likelihood that malaria will become reestablished is probably small (37). However, in countries (e.g., in the Balkans) where malaria control has ceased but the probability of transmission remains high, reintroduction could threaten the public health. Indigenous transmission associated with imported cases has recently been reported in Kazakhstan, Kyrgyzstan, Turkmenistan, Uzbekistan, Bulgaria, the Republic of Moldova, Romania, Italy, and Corsica, and the malariafree status of Europe may be in jeopardy (38). Public concern should focus on ways to deal with the realities of malaria transmission, rather than on the weather.

\section{Acknowledgments}

I am grateful to Routledge PLC for permission to include Figure 1; the Kunsthistorisches Museum, Vienna, for permission to include Figure 2; the Wellcome Institute for the History of Medicine for the use of their facilities and permission to include Figure 5; and Kevin Bruce and the Essex Record Office for Figure 6.

Dr. Reiter is chief of the Entomology Section, Dengue Branch, CDC, San Juan, Puerto Rico. His research interests include the physiology, behavior, and ecology of mosquitoes, the transmission dynamics and epidemiology of the diseases they transmit, and improved methods for their control.

\section{References}

1. Lamb HH. Climate, history and the modern world. London: Routledge; 1995.

2. Rasool SI, Schneider SH. Atmospheric carbon dioxide and aerosols: effects of large increases on global climate. Science 1971;175:138-41.

3. Calder N. The weather machine. New York: Viking; 1974.
4. Houghton JT, Meira Filho LG, Callander BA, Harris N, Kattenberg A, Maskell K, editors. The science of climate change: contribution of Working Group I to the second assessment of the Intergovernmental Panel on Climate Change. Cambridge: University Press; 1995.

5. Lindzen RS. Can increasing carbon dioxide cause climate change? Proc Natl Acad Sci U S A 1997;94:8335-42.

6. Soon W, Baliunas SL, Robinson AB, Zachary WR. Environmental effects of increased atmospheric carbon dioxide. Climate Research 1999;13:149-64.

7. Watson RT, Zinyowera MC, Moss RH, editors. Impacts, adaptations and mitigation of climate change: scientific-technical analyses. Contribution of Working Group II to the Second Assessment of the Intergovernmental Panel on Climate Change. Cambridge: University Press; 1995.

8. Patz JA, Epstein PR, Burke TA, Balbus JM. Global climate change and emerging infectious diseases. JAMA 1996;275:217-23.

9. Martens WJM, Slooff R, Jackson EK. Climate change, human health, and sustainable development. Bull World Health Organ 1997;75:583-8.

10. Epstein PR, Diaz HF, Elias S, Grabherr G, Graham NE, Martens WJM, et al. Biological and physical signs of climate change: focus on mosquito-borne diseases. Bulletin of the American Meteorological Society 1998;79:409-17.

11. Houghton JT, Meira Filho LG, Callander BA, Harris N, Kattenberg A, Maskell K, editors. The regional impacts of climate change. Cambridge: University Press; 1998.

12. Martens WJM. Health impacts of climate change and ozone depletion: an ecoepidemiologic modeling approach. Environ Health Perspect 1998;106 Suppl;241-51.

13. Bruce-Chwatt LJ, de Zulueta J. The rise and fall of malaria in Europe, a historico-epidemiological study. Oxford: Oxford University Press; 1980.

14. Grove JM. Little ice age. London: Routledge Keegan and Paul; 1988.

15. Dobson MJ. "Marsh Fever"-the geography of malaria in England. Journal of Historical Geography 1980;6:357-89.

16. Dobson MJ. Contours of death and disease in early modern England. Cambridge: Cambridge University Press; 1997.

17. Dobson MJ. Malaria in England: a geographical and historical perspective. Parassitologia 1994;36:35-60.

18. Macdonald A. On the relation of temperature to malaria in England. Journal of the Royal Army Medical Corps 1920;35:99-119.

19. Bruce-Chwatt LJ. Bruce-Chwatt's essential malariology. Gilles HM, Warrell DA, editors. London: Edward Arnold; 1993.

20. Dock G. Robert Talbor, Madame de Sévigné, and the introduction of cinchona: an episode illustrating the influence of women in medicine. Annals of Medical History 1927;4:241-7.

21. Siegel RE, Poynter FNL. Robert Talbor, Charles II and cinchona: a contemporary document. Medical History 1962;6:82-5.

22. Dobson MJ. Bitter-sweet solutions for malaria: exploring natural remedies from the past. Parassitologia 1998;40:69-81. 


\section{Perspectives}

23. Defoe D. A tour through the whole island of Great Britain. London: Penguin; 1986.

24. Russell PF. World-wide malaria distribution, prevalence, and control. Am J Trop Med Hyg 1956;5:937-65.

25. Ekblom T. Les races Suédoises de l'Anopheles maculipennis et leur role épidémiologique. Bull Soc Pathol Exot 1938;31:647-55.

26. Renkonen KO. Über das Vorkommen von Malaria in Finnland. Acta Medica Scandinavica 1944;119:261-75.

27. Faust EC. The distribution of malaria in North America, Mexico, Central America and the West Indies. In: A symposium on human malaria, with special reference to North America and the Caribbean Region. Washington: American Association for the Advancement of Science; 1941. p. 8-18.

28. Fisk GH. Malaria and the Anopheles mosquito in Canada. Can Med Assoc J 1931;Dec:679-83.

29. Macculloch J. Malaria: an essay on the production and propagation of this poison and on the nature and localities of the places by which it is produced: with an enumeration of the diseases caused by it, and to the means of preventing or diminishing them, both at home and in the naval and military service. London: Longman $\& \mathrm{Co} ; 1827$.

30. Russell PF. Man's mastery of malaria. London: Oxford University Press; 1955.
31. Loevinsohn ME. Climatic warming and increased malaria incidence in Rwanda. Lancet 1994;343:714-8.

32. McMichael AJ, Patz J, Kovats RS. Impacts of global environmental change on future health and health care in tropical countries. Br Med Bull 1998;54:475-88.

33. Hackett LW. The malaria of the Andean region of South America. Revista del Instituto de Salubridad y Enfermedades Tropicales 1945;6:239-52.

34. Reiter P. Global warming and vector-borne disease in temperate regions and at high altitude. Lancet 1998;351:839-40.

35. Mouchet J, Manguin S, Sircoulon J, Laventure S, Faye O, Onapa AW, et al. Evolution of malaria in Africa for the past 40 years: impact of climatic and human factors. J Am Mosq Control Assoc 1998;14:121-30.

36. Zulueta J. Malaria eradication in Europe. J Trop Med Hyg 1973;76:279-82.

37. Rodhain F, Charmot G. Evaluation des risques de reprise de transmission du paludisme en France. Médicine et Maladies Infectieuses 1982;12:231-6.

38. Sabatinelli G. Malaria situation and implementation of the global malaria control strategy in the WHO European region. WHO Expert Committee on Malaria 1998;MAL/EC20/98.9.

39. Molineaux L, Gramiccia G. The Garki project. Geneva: World Health Organization; 1980. 